\title{
Siebenrockiella leytensis (Taylor 1920) - Palawan Forest Turtle, Philippine Forest Turtle
}

\author{
Arvin C. Diesmos ${ }^{1}$, James R. Buskirk $^{2}$, SAbine $_{\text {Schoppe }}^{3}$, \\ Mae Lowe L. Diesmos ${ }^{4}$, Emerson Y. Sy ${ }^{5}$, AND RAFE M. Brown ${ }^{6}$ \\ ${ }^{1}$ Herpetology Section, Zoology Division, National Museum of the Philippines, \\ Padre Burgos Avenue, Ermita 1000, Manila, Philippines [arvin.diesmos@gmail.com]; \\ ${ }^{2}$ San Antonio Neighborhood Health Center, 1030 International Boulevard, \\ Oakland, California 94606 USA [Jrbuskirk@aol.com]; \\ ${ }^{3}$ Katala Foundation Inc., P.O. Box 390, Puerto Princesa City 5300, \\ Palawan,Philippines [sabine_schoppe@web.de]; \\ ${ }^{4}$ Department of Biological Sciences, College of Science, University of Santo Tomas, \\ España 1015, Manila,Philippines [maediesmos@yahoo.com]; \\ ${ }^{5}$ Herpetological Society of the Philippines, 1198 Benavidez Street, Unit 1202, \\ Tondo 1003, Manila,Philippines [emersonsy@gmail.com]; \\ ${ }^{6}$ Natural History Museum, Biodiversity Institute and Department of Ecology and Evolutionary Biology, \\ University of Kansas, Lawrence, Kansas 66045 USA [rafe@ku.edu]
}

Summary. - The Palawan Forest Turtle (or Philippine Forest Turtle), Siebenrockiella leytensis (Family Geoemydidae), is one of the most enigmatic species of freshwater turtles in Southeast Asia, and has been surrounded with more confusion and misconception than almost any other turtle in the region. For over 80 years, its true geographic distribution in the Philippines remained a mystery; its apparent rarity and the rudimentary knowledge of its ecology and natural history had bestowed upon it an almost mythical reputation. Long thought to come from the eastern Philippine island of Leyte, it was very recently discovered to actually occur in the Palawan region of the western Philippines. The species is the largest and heaviest geoemydid turtle known from the Philippines, attaining a carapace length of more than $300 \mathrm{~mm}$ and weighing as much as $3.5 \mathrm{~kg}$. Known clutch size is 1-2, and eggs average $49.6 \times 26.5 \mathrm{~mm}$ in size and weigh 18-30 g. As predicted by previous workers, the recent discovery of a natural population of $S$. leytensis on Palawan has already spurred a collecting frenzy among wildlife trappers and traders to supply domestic and international markets for the illegal wildlife trade. In spite of its official protected status in local and international listings, the illegal trade in S. leytensis is rampant and is perceived currently as the greatest threat to the species. This threat is exacerbated by the continuing destruction of the lowland forests of Palawan, the primary habitat of the species. If the current trend of overexploitation continues, it is certain that several subpopulations of $\boldsymbol{S}$. leytensis will soon collapse. In the face of these threats, wildlife authorities on Palawan must immediately enforce relevant laws and encourage greater coordination among appropriate government agencies that typically work in isolation. Conservation programs need to prioritize efforts that will curb illegal collection of S. leytensis and other threatened species and monitor known populations. Top priority research studies for $S$. leytensis include population biology, ecology, and in-depth investigation of the dynamics of illegal trade in the species.

Distribution. - Philippines. The species appears to be restricted to the northern half of the island group of Palawan in western Philippines. It does not occur at the erroneous original type locality of Leyte Island in eastern Philippines.

Synonymy. - Heosemys leytensis Taylor 1920, Geoemyda leytensis, Siebenrockiella leytensis, Siebenrockiella (Panyaenemys) leytensis, Panyaenemys leytensis.

SubsPECIES. - None.

STATUS. - IUCN 2012 Red List: Critically Endangered (CR A2d, B1+2c) (assessed 2000); TFTSG Draft Red List: Critically Endangered; CITES: Appendix II; Philippines: Republic Act 9147 (Wildlife Resources Conservation and Protection Act).

Taxonomy. - Heosemys leytensis was described by Edward H. Taylor in 1920 based on two unnumbered specimens that were retrieved from a zoological laboratory in the University of the Philippines, Manila (Taylor
1920). He placed the species in the genus Heosemys based primarily on the absence of a temporal arch (Taylor 1920). Among the additional characters that established its affinity with the genus Heosemys were the broad bridge between 


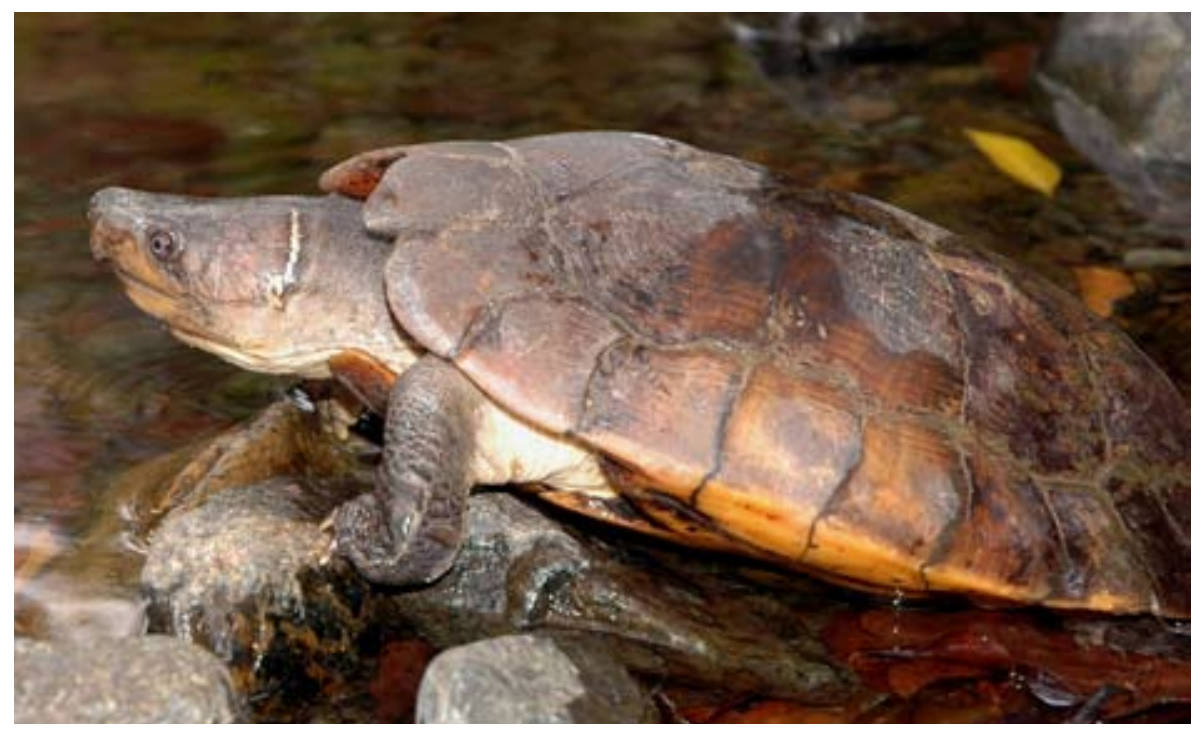

Figure 1. Adult male Siebenrockiella leytensis in its primary habitat on Palawan, the lowland riparian forests from the northern region of the island. These lowland habitats are imperiled because of slash-and-burn farming, timber poaching, charcoal making, and the impacts of mining and quarrying. Photo by Rafe Brown.

the plastron and carapace, the entoplastron intersected by the humeropectoral suture, the lack of quadratojugal bones, and the rudimentary scalation of the head (Buskirk 1989; Ernst and Barbour 1989; Ernst et al. 2000). Wermuth and Mertens (1961) suppressed Heosemys and allocated most of its member species to Geoemyda, a placement that was rejected by McDowell (1964), citing the distinctive skull anatomy of turtles within the group (see also Ernst and Barbour 1989). Nonetheless, some authors subsequently considered leytensis as a species of Geoemyda (review in Iverson 1992). McCord et al. (2000) proposed that leytensis, along with the Indian species silvatica, remain in Heosemys until more robust information on the systematics of these taxa indicated otherwise.

Spinks et al. (2004), in a phylogenetic study of turtles of the family Geoemydidae, demonstrated the potential nonmonophyly of Heosemys, but declined to make taxonomic conclusions pending further phylogenetic investigations.

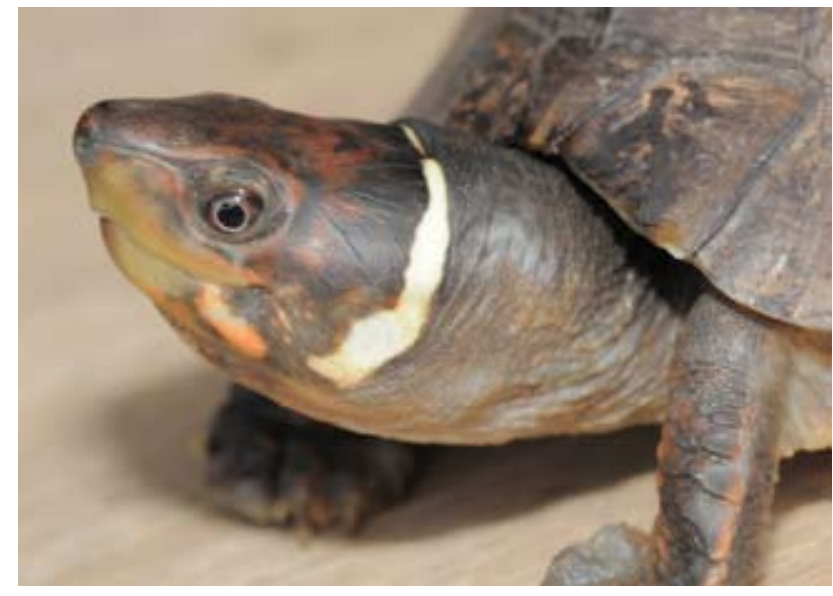

Figure 2. Subadult Siebenrockiella leytensis. Photo by Emerson Sy.
Heosemys leytensis was not included in their phylogenetic analyses due to lack of genetic samples. Following the recent rediscovery of the species (Diesmos et al .2004), morphological study and molecular phylogenetic analysis demonstrated that leytensis is the sister lineage to the previously monotypic Sundaic turtle genus Siebenrockiella (Diesmos et al. 2005). Thus, S. leytensis is the sister species to $S$. crassicollis, a species that occurs from Peninsular Malaysia to Borneo (Ernst et al. 2000). Nonetheless, there is high genetic divergence (ca.13\% cytb) between S. leytensis and S. crassicol-

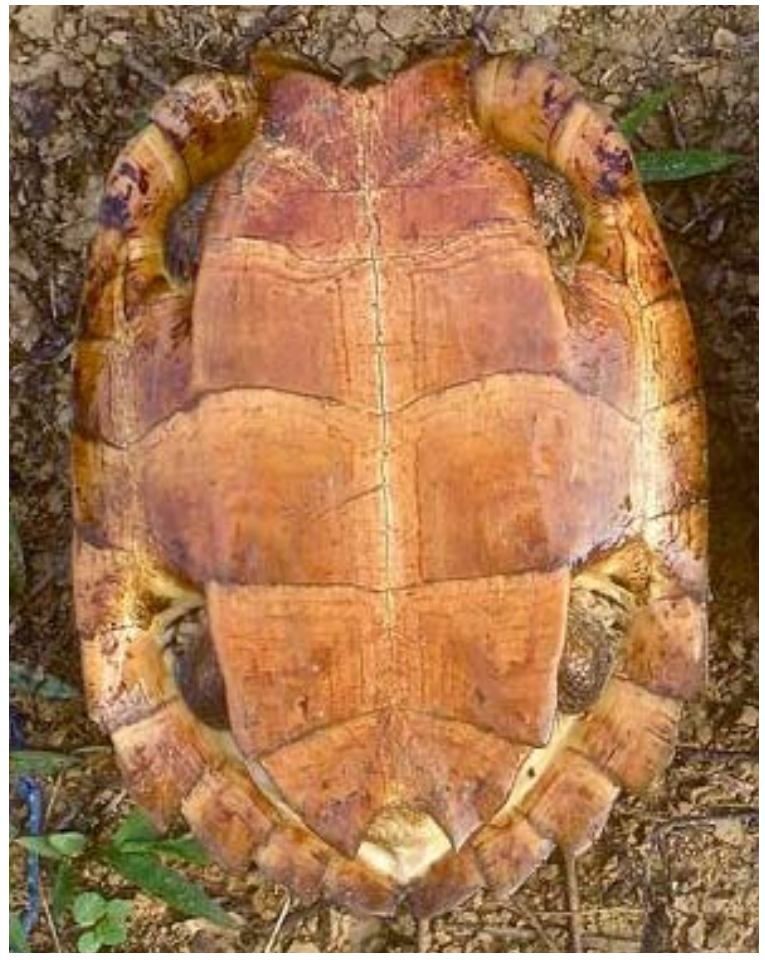

Figure 3. Adult Siebenrockiella leytensis. Photo by Sabine Schoppe. 


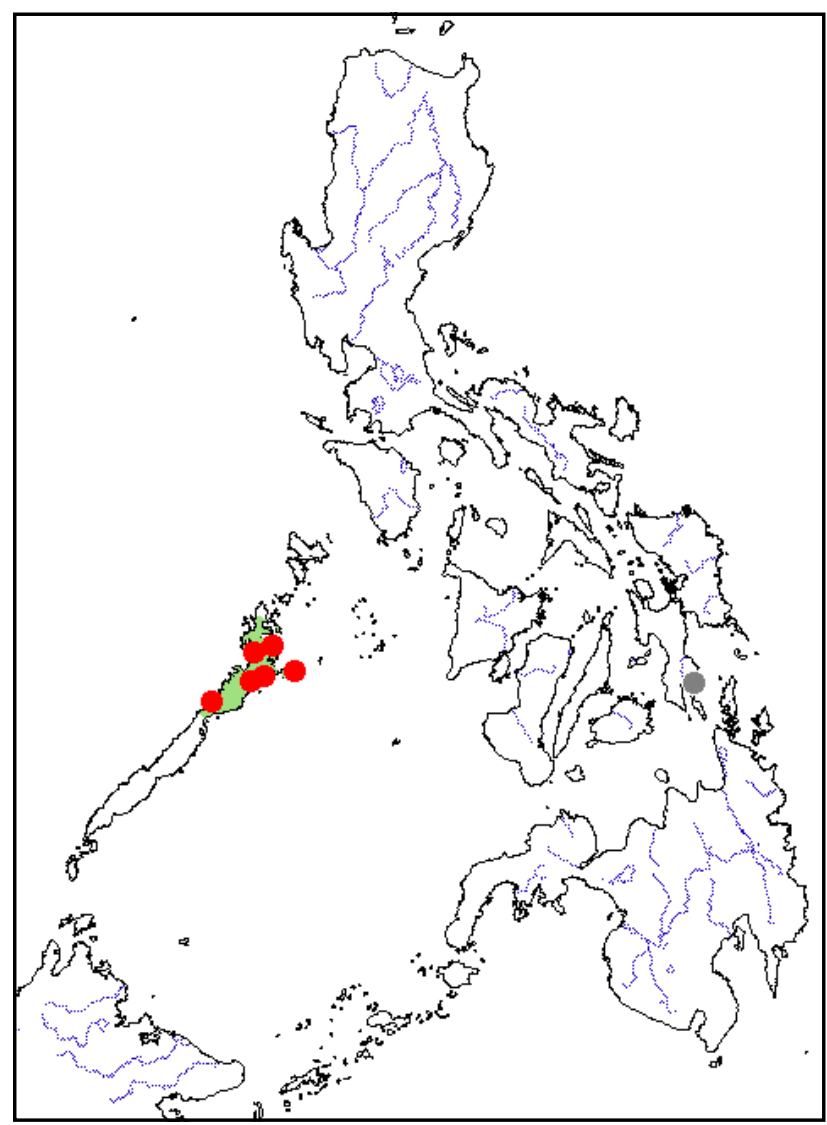

Figure 4. Distribution of Siebenrockiella leytensis in the Palawan Island group in the Philippines. Red dots $=$ museum and literature occurrence records of native populations based on Iverson (1992), plus more recent and authors' data; gray dot $=$ erroneous original type locality on Leyte Island; green shading = projected native distribution based on GIS-defined hydrologic unit compartments (HUCs) constructed around verified localities and then adding HUCs that connect known point localities in the same watershed or physiographic region, and similar habitats and elevations as verified HUCs (Buhlmann et al. 2009), and adjusted based on authors' data.

lis, prompting Diesmos et al. (2005) to erect the subgenus Panyaenemys (etymology:panya-en, "enchanted" and emys, "turtle") to accommodate the distinct Philippine lineage (see also Philippen 2006; Vetter and van Dijk 2006).

Restriction of Type Locality. - The historical record of $S$. leytensis from the island of Leyte in east central Philippines ("Cabalian, southern Leyte"; fide Taylor 1920) - long designated as the type locality -is erroneous and resulted from a mislabeling of the type specimens (Diesmos et al. 2008). In accordance with the provisions of Article 76 of the International Code of Zoological Nomenclature (ICZN 1999), we consider it advisable to correct the error at this time.

The types of S. leytensis (holotype, one paratype, and neotype; Taylor 1920; Buskirk 1989) were collected by G.F. Lopez, a seasoned field collector from the Philippine Bureau of Science (now the National Museum of the Philippines). Lopez was known to have collected specimens for Taylor and served as his field assistant. During the course of Tay- lor's decades of pioneering work in Philippine herpetology (Diesmos and Brown 2011), Taylor amassed a sizeable herpetological collection, most of which is now housed at the California Academy of Sciences (CAS), Field Museum of Natural History (FMNH), Museum of Comparative Zoology (Harvard University), and Carnegie Museum. The herpetological collection databases of CAS (http://research. calacademy.org/herp/collections) and FMNH (http://fm1. fieldmuseum.org/collections) reveal that Lopez collected amphibians and reptiles from the northern regions of Palawan Island and from the islands of Coron and Busuanga in the Calamian group, north of Palawan (see also Taylor 1922a, 1922b, 1923, 1925; Buskirk 1989). It is therefore a logical assumption that the types of $S$. leytensis most likely originated from northern Palawan or the Calamian group of islands. But since up to now S. leytensis has only been confirmed to occur in northern Palawan, we hereby restrict the type locality of S. leytensis to "northern Palawan in the Province of Palawan, Philippines."

Description. - The Palawan Forest Turtle is the largest and the heaviest geoemydid turtle known from the Philip-

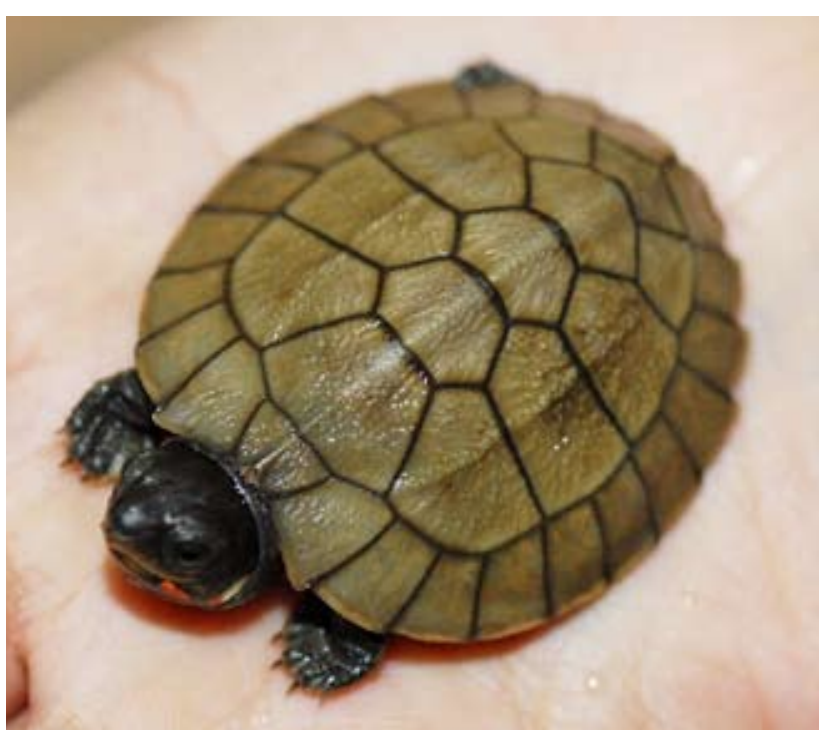

Figure 5. Hatchling Siebenrockiella leytensis. Photo by Emerson Sy.

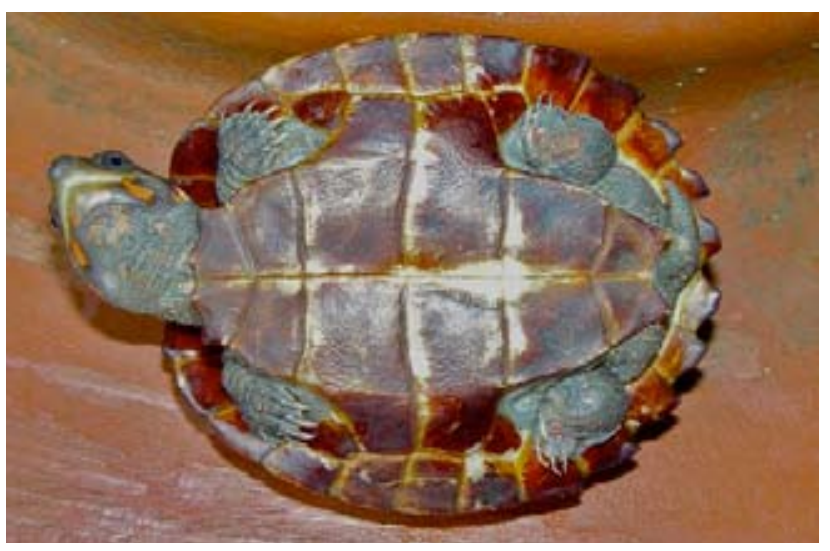

Figure 6. Juvenile Siebenrockiella leytensis. Photo by Sabine Schoppe. 


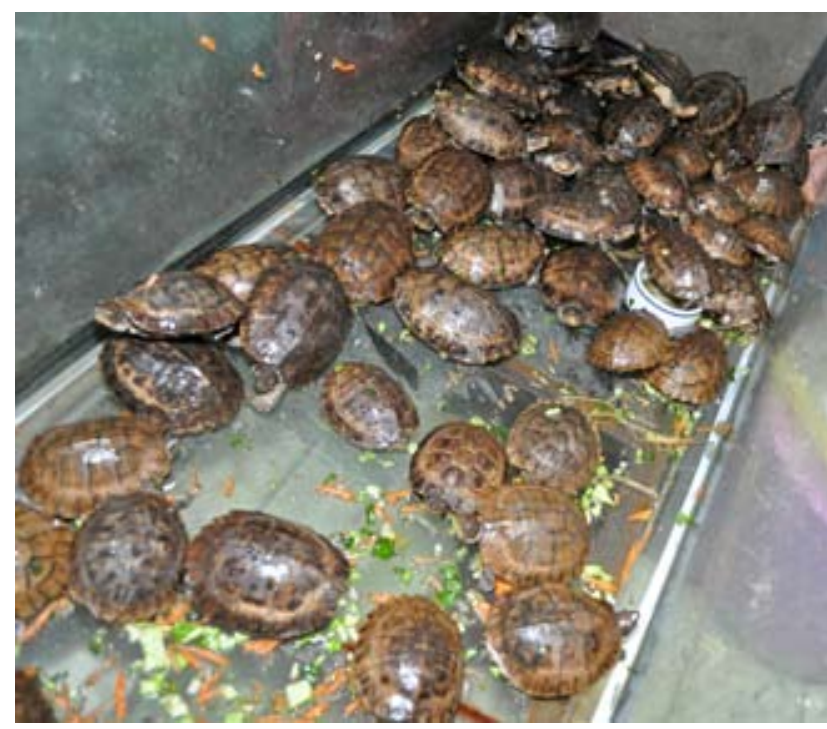

Figure 7. Illegal wildlife trade of S. leytensis is the greatest threat to the species. Over a thousand juvenile and adult turtles have already been smuggled out of Palawan to supply the illegal trade. Photo by Emerson Sy.

pines. Old adults attain a median carapace length (MCL) of more than $300 \mathrm{~mm}$, a median plastron length (MPL) of over $220 \mathrm{~mm}$, and weigh as much as $3.5 \mathrm{~kg}$. Hatchlings are typically $\leq 46 \mathrm{~mm}$ MCL. Range of measurements of 325 specimens is as follows (Schoppe, unpubl. data).

Immature turtles of undetermined sex $(n=190)$ : maximum carapace length, MCL, $41.0-170.0 \mathrm{~mm}$ (mean $=124.2$ \pm 37.2 ); maximum carapace width, $\mathrm{MCW}, 36.5-130.0 \mathrm{~mm}$ (mean $=95.0 \pm 24.4)$; maximum plastron length, MPL, 33.5-152.0 $\mathrm{mm}($ mean $=105.7 \pm 32.8)$; plastron width, PW, 25.3-109.0 mm (mean = 73.7 \pm 20.9$)$; body height, $\mathrm{BH}, 20.5-78.0 \mathrm{~mm}$ (mean $=50.9 \pm 13.2)$; tail length, $\mathrm{TL}$, 3.2-21.0 mm (mean = 12.3 \pm 3.7$)$; body mass, $10-950 \mathrm{~g}$ $($ mean $=341.7 \pm 223.3)$.

Adult males $(\mathrm{n}=76)$ : MCL, 175.0-299.0 mm (mean $=223.5 \pm 33.7) ; \mathrm{MCW}, 127.0-226.0 \mathrm{~mm}($ mean $=172.9 \pm$ 26.0); MPL, 137.0-222.0 mm (mean = 188.4 \pm 23.5$)$; PW, 94.0-178.0 mm (mean = 132.9 \pm 19.5); BH, 63.0-109.0 $\mathrm{mm}($ mean $=85.7 \pm 11.7) ; \mathrm{TL}, 9.7-41.3 \mathrm{~mm}($ mean $=26.4$ \pm 6.6 ); body mass, $810-3580 \mathrm{~g}$ (mean $=1799.5 \pm 714.2)$.

Adult females ( $\mathrm{n}=49)$ : MCL, 172.0-212.0 mm (mean $=190.6 \pm 9.6) ; \mathrm{MCW}, 124.0-159.0 \mathrm{~mm}($ mean $=141.3 \pm$ 7.7); MPL, 140.0-178.0 mm (mean $=161.1 \pm 8.5)$; PW, 96.0-138.0 mm (mean = 110.7 \pm 8.0$) ; \mathrm{BH}, 64.0-92.0 \mathrm{~mm}$ $($ mean $=77.2 \pm 7.0) ; \mathrm{TL}, 10.4-24.0 \mathrm{~mm}($ mean $=18.0 \pm 3.9)$; body mass, $770-1400 \mathrm{~g}$ (mean $=1081.1 \pm 161.0)$.

Sexual dimorphism is less prominent in subadult and sexually immature turtles. Adult male turtles are distinguished from adult females by their slightly concave plastron at the posterior end and by their longer and thicker tail. The plastron of large females is flat or slightly convex. Sexual maturity is probably reached at $200 \mathrm{~mm} \mathrm{MCL} \mathrm{(Schoppe,} \mathrm{unpubl.} \mathrm{data).}$ Males are generally larger than females.
The carapace of S. leytensis is wide, somewhat flattened, and heavily buttressed. A vertebral keel is present in juveniles, gradually becomes less prominent in subadults, and is usually absent in adults. The anterior marginal scutes are blunt and rounded in juveniles; with age the first two marginals project forward into a serrated rim. The posterior marginals are serrated during various life history stages in both males and females, but the serrations usually wear away in old females. There are four costals and usually 12 (range, 11-13) marginals on each side of the carapace, although some specimens may exhibit an uneven number of marginals. In old adults, a collar is formed by two extremely projecting marginals on either side of the nuchal scute, which extends well beyond the rim of the carapace; the gulars are also strongly projecting. Vertebral 1 is mushroom-shaped, vertebrals 2-4 are ginkgo leaf-shaped, and vertebral 5 is more or less hexagonal (Diesmos et al. 2005). The plastron is unhinged, ovoid, and is notched anteriorly and posteriorly. The anal plate has a deep gap and is either round or $\mathrm{V}$-shaped. Plastral formula varies greatly.

The head is large, the snout projecting and rounded, and the nostrils are placed anteriorly. There are 6-7 large tubercles above the upper eyelids. The upper jaw is slightly hooked and bicuspid with corresponding indentations on the lower jaw. The anterior surface of the forelimbs and hind limbs has 3-5 enlarged transverse scales; the forelimb has a large transverse scale on the heel, which is not found on the hind limb. The toes are fully webbed. All five digits of the forefoot bear a sharp, curved claw while only four digits of the hind foot have claws; the fifth has no claw.

Carapace color varies from chestnut brown, dark brown, pale yellow to pale brown. Plastron and bridge coloration varies from chestnut brown to pale yellow with a pattern of black blotches in some individuals, without a radiating color pattern. The head is dark brown with a typical black patch on the crown and rostrum. There are pink-orange spots on the sides of head, temporal region, and lower jaw. A distinctive narrow white or yellowish band crosses the head transversely just behind the tympanic region, which may or may not be medially divided. The transverse band and pink-orange spots on the head fade with age and may be completely absent in old individuals, especially in males. Coloration of limbs and tail varies from pale yellow to dark gray.

Distribution. - In the past, the apparent rarity of $S$. leytensis and misconceptions about its origin have triggered discussion about its distribution pattern (e.g., Gaulke and Fritz 1998; Gaulke and Altenbach 2006). It is only recently that it has been established with certainty that S. leytensis is endemic to the Philippines, that it does not occur on Leyte Island, and that it is instead actually restricted to the Palawan group of islands in the western region of the archipelago (Diesmos et al. 2004; Fidenci 2004; Diesmos et al. 2008; Schoppe et al. 
2010). This chain of islands, referred to biogeographically as Palawan Pleistocene Aggregate Island Complex or Palawan PAIC (Brown and Diesmos 2002, 2009), is renowned for its biotic affinity with islands to the southwest in the Sunda Shelf and is biologically distinct from the rest of the Philippines (Heaney 1986). Regardless, the Palawan PAIC retains a significant number of endemic fauna and flora not found in the Sundaic region (Widmann 1998; McGuire and Alcala 2000; Brown and Guttman 2002; Evans et al. 2003). Siebenrockiella leytensis is known from northern Palawan (in the municipalities of Roxas, San Vicente, and Taytay), on the island of Dumaran northeast of Palawan, and from Puerto Princesa in the west central region of the island. There are unconfirmed records of the species from the islands of Coron, Culion, and Busuanga in the Calamian island group north of Palawan (Schoppe et al. 2010; D. Acosta, unpubl. data).

Habitat and Ecology. - The Palawan Forest Turtle lives in forest habitats near sea level up to an altitude of about $300 \mathrm{~m}$. Primary habitat is pristine lowland forest but the species has been found in disturbed and fragmented forests, second growth vegetation, and in cultivated areas (such as flooded rice fields) that are adjacent to remnant original forests (Schoppe et al. 2010). The species inhabits streams, creeks, moderate-sized rivers, inland freshwater lakes, and freshwater swamps (Fidenci 2004; Diesmos et al.2008). Adult turtles are semi-aquatic, whereas hatchlings and juveniles appear to be fully aquatic (Schoppe 2006). It is a nocturnal species. Siebenrockiella leytensis shares its habitat with Cyclemys dentata and Cuora amboinensis.

During the day, S. leytensis has been found ensconced under rocks and boulders or in burrows located on the banks of streams and rivers. At night, turtles actively forage along sandy shores and in stationary pools of streams and rivers. The species may be found deep in the forest interior, especially during the warmest months of the year when most streams and small rivers have dried up. Siebenrockiella leytensis preys on fish, crabs, shrimp (genus Macrobrachium), and freshwater gastropods of the family Thiaridae (Schoppe 2006); it also feeds on algae and wild fruits, especially ripe figs (Diesmos et al.2008). The assumption of Schoppe (2010) that $S$. leytensis feeds on the golden apple snail (Pomacea canaliculata), an invasive alien pest species that is widely found in rice fields on Palawan, has been confirmed by an ongoing study (Schoppe, unpubl. data).

The reproductive biology and natural history of the species remain poorly understood. Females have been observed to lay 1-2 eggs. The eggs are brittle-shelled, oblong, and pale pink in color. In captivity, turtles laid eggs from June through December (Yuyek 2004; Diesmos et al. 2008; Schoppe, unpubl. data). Measurements of eggs laid by captive turtles $(\mathrm{n}=19)$ ranged from $41.0-57.8 \mathrm{~mm}$ in length (mean $=49.6 \pm 3.9), 19.7-29.4 \mathrm{~mm}$ in width $($ mean $=26.5 \pm 2.7)$, and weighed $18-30 \mathrm{~g}($ mean $=24.0 \pm 4.3)$. Juvenile turtles and hatchlings have been found in the wild during the dry season (January-April) (Widmann et al.2004; Schoppe 2006, 2008a). Wildlife poachers claim that $S$. leytensis oviposits in deep burrows located on near-vertical banks of streams and rivers.

Growth rate in $S$. leytensis decreases with increasing body size (Schoppe 2006, 2008a). Captive juvenile turtles measuring 46, 55, and $75 \mathrm{~mm}$ MCL grew at a rate of 0.10 , 0.10 , and $0.09 \mathrm{~mm} /$ day, respectively, whereas larger juveniles (82 and $120 \mathrm{~mm}$ MCL) grew $0.02 \mathrm{~mm} /$ day. Growth rate of an adult male (225 $\mathrm{mm}$ MCL) was $0.03 \mathrm{~mm} /$ day. In wild populations, mean juvenile growth rate was $0.07 \mathrm{~mm} /$ day (Schoppe 2006, 2008a).

Population Status. - For over 80 years since the species was described, the failure of herpetologists to find $S$. leytensis at its alleged type locality on the island of Leyte, combined with a general absence of information on its ecology and natural history, led many to conclude that it was an extremely rare species (Taylor 1920; Alcala 1986; Buskirk 1989; Ernst and Barbour 1989; Das 1995; Gonzalez et al. 1997; Gaulke and Fritz 1998; van Dijk et al. 2000; Gaulke and Altenbach 2006). Data collected since the time of its rediscovery on Palawan (Diesmos et al. 2004; Fidenci 2004) indicate that S. leytensis is not locally rare at all (Diesmos et al.2008; Schoppe et al.2010). Estimates of population density of $S$. leytensis from several locations in northern Palawan range from 4 to 121 turtles/ha (Acosta 2006; Schoppe et al. 2010).

Results of field surveys, however, reveal a decreasing trend in abundance, especially in areas where turtles are heavily collected (Schoppe and Cervancia 2009; Schoppe et al. 2010). On the other hand, wildlife poachers suggest that S. leytensis is "as common" as the other geoemydid turtles found on Palawan (i.e., Cuora amboinensis and Cyclemys dentata), but since it is such an elusive species, it is apparently not encountered as often as the other two (Diesmos et al. 2008).

Threats to Survival. - Exploitation for the illegal wildlife trade is the single and most important threat to the Palawan Forest Turtle. Since its rediscovery (Diesmos et al. 2004; Fidenci 2004; Widmann et al. 2004), we estimate that well over 1000 S. leytensis have already been collected from and smuggled out of Palawan to supply the illegal pet trade within and outside of the Philippines (Yuyek 2004; Diesmos et al. 2008; Fidenci and Maran 2009; Diesmos et al., pers. obs.). Collection of turtles for the illegal trade is unrelenting and indiscriminate. In 2004 over 70 S. leytensis of various age and size were found stockpiled in a single holding facility in Puerto Princesa City, and over 200 were found in one such facility in Manila (Gavino and Schoppe 2005; Sy, unpubl. data). In May 2010, over 1100 turtles of various species (including 74 S. leytensis) intended for animal 
markets in China were confiscated by wildlife authorities on Palawan (Anda 2010; Schoppe, pers. obs.).

The northern Palawan subpopulations of S. leytensisparticularly those from Taytay - are likely to be the source of most, if not all, illegally caught turtles that are available in the pet trade. From the period 2004 to 2010, wildlife authorities on Palawan have seized over 600 S. leytensis that were being shipped out from a single seaport in Taytay (Lopez and Schoppe 2004; KFI 2007; Diesmos et al. 2008; Anda 2010; Schoppe et al.2010). Data are lacking from other strategic seaports in the region where wildlife trafficking undoubtedly occurs; such routes typically lack facilities and trained personnel to monitor illegal wildlife trade (LepitenTabao and Tabaranza 2004; Diesmos et al. 2008; Schoppe et al. 2010). Despite the absence of quantitative population analysis, we predict that the northern Palawan population of S. leytensis may soon collapse.

Wildlife traders purchase turtles from poacherstypically for a low price-and ship the animals to Manila, Cebu, and Davao through illegal channels. These major cities serve as trans-shipment points. Wildlife traffickers then transport the animals to destinations across Southeast Asia, Indochina, China, Japan, Europe, and the USA (Gavino and Schoppe 2004; Yuyek 2004; Diesmos et al. 2008; Fidenci and Maran 2009; Schoppe et al. 2010). In Manila, S. leytensis is routinely sold in Cartimar, a hugely popular pet market that also serves as a major trading center for S. leytensis and other threatened species of vertebrates (Fidenci and Maran 2009; Sy and Schoppe, unpubl. data; Diesmos et al., pers. obs.).

We have gathered compelling evidence that certain zoos and wildlife rescue and nature centers that are involved in trade of S. leytensis (and other threatened and/or charismatic species) falsely claim their animals as "captive-bred" when in fact, they were sourced from wild populations (Sy, unpubl. data; Diesmos et al., pers. obs.). This practice is becoming increasingly common elsewhere in Southeast Asia (Schoppe 2008b,2009b) and warrants in-depth investigation by wildlife authorities in the Philippines.

Habitat loss and degradation remain major threats to the species. Although Palawan is widely promoted as the "last ecological frontier" of the Philippines (see Anda and Tabangay 2004), the region continues to lose critical habitats-especially the lowland forest-through timber poaching, mining, quarrying, charcoal-making, and slashand-burn farming (Mallari et al. 2001; Anda and Tabangay 2004; Diesmos and Palomar 2004; Diesmos et al. 2008; Diesmos and Brown 2011).

Like most other species of turtles in the Philippines, S. leytensis is considered an important source of protein by some groups of people. Collection for food was found to be the most significant threat to $S$. leytensis in some areas on Palawan (Schoppe et al. 2010). This and other species of turtles are also used in traditional medicine. In addition, turtle body parts, especially the carapace, are fashioned into curio items either for non-commercial use or are sold to tourists. These forms of utilization are being carried out by members of indigenous peoples groups and by the economically marginalized populace (Acosta 2006; Diesmos et al. 2008; Matillano 2008; Schoppe et al. 2010).

Conservation Measures Taken. - Siebenrockiella leytensis has been listed as Critically Endangered on the IUCN Red List (IUCN 2012) since 2000 and is included in Appendix II of CITES (CITES 2011). Its IUCN Red List status was provisionally reaffirmed as Critically Endangered by the IUCN Tortoise and Freshwater Turtle Specialist Group in 2011 (Turtle Taxonomy Working Group 2011), and the species was included among the world's top 25 most endangered tortoises and freshwater turtles in 2011 (Turtle Conservation Coalition 2011). It is a nationally protected species by virtue of Republic Act 9147 (Wildlife Resources Conservation and Protection Act), the violation of which carries a penalty of heavy fines including imprisonment (Anonymous 2001; DENR 2004; PCSD 2006).

The species occurs in several protected areas in the Palawan region, which provides some protection for a number of its subpopulations. Since 2006, Katala Foundation Inc. (KFI, a Palawan-based conservation NGO) and the Philippine government (through the Protected Areas and Wildlife Bureau of the Philippine Department of Environment and Natural Resources and the Palawan Council for Sustainable Development) have implemented various conservation projects under the Philippine Freshwater Turtle Conservation Program (PFTCP) in Palawan. Apart from efforts that emphasize research and conservation management of $S$. leytensis and other species, the program aims to strengthen law enforcement capacities of wildlife authorities on Palawan to reduce illegal collection and trade through communitybased anti-wildlife trafficking monitoring groups (Schoppe and Acosta 2010b; Schoppe and Ibañez 2011).

KFI has also established an assurance colony on Palawan for captive conservation breeding of S. leytensis and other species (Schoppe and Fernando 2009; Schoppe 2010; Schoppe and Diaz 2011).

Conservation Measures Proposed. - The uncontrolled exploitation of S. leytensis for the illegal trade is primarily due to a lack of enforcement by government authorities of the relevant national and international policies on wildlife conservation and trade. Environmental agencies in the Philippines are generally unaware of the extent of illegal wildlife trade in the country. Worse, most agencies are ill-equipped and under-trained to monitor and control this problem (Lepiten-Tabao and Tabaranza 2004; Diesmos et al. 2008).

In light of the relentless and indiscriminate collection of the species, we recommend the uplisting of S. leytensis to 
CITES Appendix I. We believe that this proposed category is more reflective of the present conservation status of the species. Placing S. leytensis in the highest possible category of CITES will offer another level of protection to wild populations and may considerably reduce illegal trade of the species. We also consider in-situ conservation of S. leytensis and of its habitat, together with effective law enforcement to reduce illegal trade, as high priority conservation strategies for the species.

Because the lack of effective enforcement of wildlife laws is the biggest setback to current conservation efforts for $S$. leytensis, we propose that large samples of known populations of the species be genotyped using multiple, variable, unlinked genetic loci (mitochondrial and nuclear gene sequences and/or microsatellites) and that a freely accessible, web-based genetic database be established. Such an enforcement tool would allow trade forensics and determination of geographic origin of confiscated animals (Welton et al., in press). A resource such as this would serve as a deterrent for poachers and smugglers who might otherwise be able to claim that animals in their possession were "captive-bred." At present, no genetic enforcement resources are available to wildlife managers in the Philippines and there is little hope for informed management or reintroduction of confiscated trade animals.

Current Research. - Several local and international groups are currently conducting field surveys to gather additional important information on the distribution, population ecology, habitat requirements, captive husbandry, and illegal trade and exploitation of the species. In partnership with academic institutions and wildlife agencies on Palawan, KFI is leading public awareness campaigns that are designed to improve law enforcement against illegal wildlife trade. Long-term studies on population trends, ecology, and life history of S. leytensis are also being undertaken by KFI since 2008 (Schoppe 2009b; Schoppe and Acosta 2010a, 2011, 2012).

Acknowledgments. - Survey work for S.leytensis from 2001-03 was made possible through generous funding and technical support by BP Conservation Programme (Herp Watch Palawan 2001 Project no. 1554), Royal Melbourne Zoological Gardens, North of England Zoological Society, Conservation International Philippines, Turtle Conservation Fund (TCF), Turtle Survival Alliance (TSA), Fauna \& Flora International, National Museum of the Philippines, Palawan Council for Sustainable Development, and the Protected Areas and Wildlife Bureau of the Philippine Department of Environment and Natural Resources. The European Association of Zoos and Aquaria-Shellshock Campaign, TCF, TSA, Chester Zoo, Zoological Society for the Conservation of Species and Populations, U.S. Fish and Wildlife Service, Cleveland Metro Parks, Idea Wild, and the Philippine Cockatoo Conservation Program supported research and conservation programs of Katala Foundation Inc. since 2007. Our 2007 Palawan biodiversity fieldwork was funded by the U.S. National Science Foundation (DEB 0743491) and the University of Kansas. For various help during our surveys of S. leytensis, we are grateful to Diverlie Acosta, Nonito Antoque, Debbie van den Beukel, Siegfred Diaz, Jason Diesmos, Jeff Diesmos, Jude Dimalibot, Rolito Dumalag, Pierre Fidenci, Genevieve Gee, Snapper Poche, RogerSison, and Peter and Indira Widmann. We thankAnders Rhodin, Peter Paul van Dijk, John Iverson, and Raymond Saumure for reviewing, editing, and publishing this species account.

\section{LITERATURE CITED}

AcostA,D.D.2006. Population structure of the PhilippineForest Turtle Siebenrockiella P. leytensis (Taylor, 1920) in Dumarao, Roxas, Palawan,Philippines.B.Sc.Thesis, Western Philippines University, Puerto Princesa City, Palawan, Philippines.

Alcala, A.C. 1986. Amphibians and Reptiles. Guide to Philippine Flora and Fauna Vol. X. Natural Resources Management Center and University of the Philippines, Manila, $195 \mathrm{pp}$.

ANDA, R.D. 2010. Crackdown set vs poachers after raid on Palawan farm. Philippine Daily Inquirer May 30, 2010. A15.

ANDA, R.D. AND TabangaY-BAldeRA, J.G. (Eds.). 2004. Surublien: Strategies to Conserve Palawan's Biodiversity. Provincial Government of Palawan, Palawan Council for Sustainable Development Staff, Department of Environment and Natural Resources-MIMAROPA Region IV,Palawan NGO Network Inc., and Conservation International Philippines. Puerto Princesa City, Philippines, $124 \mathrm{pp}$.

ANONYMOus. 2001. Republic Act 9147. An act providing for the conservation and protection of wildlife resources and their habitats, appropriating funds therefore and for other purposes. Republic of the Philippines, Congress of the Philippines, Eleventh Congress.

Brown, R.M. AND Diesmos, A.C. 2002. Application of lineage-based species concepts to oceanic island frog populations: the effects of differing taxonomic philosophies on the estimation of Philippine biodiversity. Silliman Journal 42(1):133-162.

Brown, R.M. AND Diesmos, A.C. 2009. Philippines, Biology. In: Gillespie, R. and Clague, D. (Eds.). Encylopedia of Islands. University of California Press, Berkeley, pp. 723-732.

Brown, R.M. AND Guttman, S.I. 2002. Phylogenetic systematic of the Rana signata complex of Philippine and Bornean stream frogs; reconsideration of Huxley's modification of Wallace's Line at the Oriental-Australian faunal zone interface. Biological Journal of the Linnean Society 76:393-461.

Buhlmann, K.A., Akre, T.S.B., Iverson, J.B., Karapatakis, D., MitTermeIER, R.A., Georges, A., RHODIN, A.G.J., vAN DiJK, P.P., AND GiBbons, J.W. 2009. A global analysis of tortoise and freshwater turtle distributions with identification of priority conservation areas. Chelonian Conservation and Biology 8:116-149.

BUSKIRK,J.R. 1989.Athird specimen and neotype of Heosemys leytensis (Chelonia: Emydidae). Copeia 1989:224-227.

CITES [CONVENTION ON INTERNATIONAL TRADE INENDANGERED SPECIES OF WILD FAUNA AND FlORA]. 2011. Appendices I, II and III. www.cites. org/eng/append/ appendices.shtml.

DAS, I. 1995. Status of knowledge on the biology and conservation of non-marine turtles of the Philippines. Gonfaron,France: International 
Congress of Chelonian Conservation, Abstracts, p. 10.

DENR [DEPARTMENT OFENVIRONMENT AND NATURAL RESOURCES]. 2004. DENR Administrative Order No. 2004-15. Establishing the list of species and their categories, and the list of other wildlife species under the jurisdiction of DENR pursuant to Republic Act No. 9147, otherwise known as the Wildlife Resource Conservation and Protection Act of 2001. Department of Environment and Natural Resources, Quezon City, Philippines.

Diesmos, A.C. AND Brown, R.M. 2011. Diversity, biogeography, and conservation of Philippine amphibians. In: Das, I., A. Haas, and A.A. Tuen (Eds.). Proceedings of the Conference: Biology of the Amphibians in the Sunda Region, Southe-east Asia. Institute of Biodiversity and Environmental Conservation, Universiti Malaysia Sarawak, Kota Samarahan, pp. 26-49.

Diesmos, A. And Palomar, N. 2004. The status of biological diversity in the Palawan Corridor. In: Anda, R.D. and J.G.Tabangay-Baldera (Eds.). Surublien: Strategies to Conserve Palawan's Biodiversity. Provincial Government of Palawan,PalawanCouncil for Sustainable Development Staff, Department of Environment and Natural Resources-MIMAROPA Region IV, Palawan NGO Network Inc., and Conservation International Philippines. Puerto Princesa City, Philippines, pp. 1-7.

Diesmos, A.C., Gee, G.V.A., Diesmos, M.L., Brown, R.M., Widmann, P.J., AND DimaLiBot, J.C. 2004. Rediscovery of the Philippine forest turtle, Heosemys leytensis (Chelonia; Bataguridae), from Palawan Island, Philippines. Asiatic Herpetological Research 10:22-27.

Diesmos, A.C., Parham, J.F., Stuart, B.L., AND Brown, R.M. 2005. The phylogenetic position of the recently rediscovered Philippine forest turtle (Bataguridae: Heosemys leytensis). Proceedings of the California Academy of Sciences 56(3):31-41.

Diesmos, A.C., Brown, R.M., Alcala, A.C., AND Sison, R.V. 2008. Status and distribution of non-marine turtles of the Philippines. Chelonian Conservation and Biology 7(2):157-177.

ERnSt, C.H. AND BARBOUR, R.W. 1989. Turtles of the World. Washington, DC: Smithsonian Institution Press, 290 pp.

ERnst, C.H., Altenburg, R.G.M., And Barbour, R.W. 2000. Turtles of the world. ETI Expert Center for Taxonomic Identification and World Biodiversity Database CD-ROM Series.

Evans, B.J., Brown, R.M., McGuire J.A., Supriatna, J., Andayani, N., Diesmos, A., Iskandar, D., Melnick, D.J., and Cannatella, D.C. 2003. Phylogenetics of fanged frogs: testing biogeographical hypotheses at the interface of the Asian and Australian faunal zones. Systematic Biology 52:794-819.

FIDENCI, P. 2004. Discovery of a wild population of the critically endangered Philippine Forest Turtle Heosemys leytensis, in Palawan, Philippines. Turtle and Tortoise Newsletter 8:2-3.

Fidenci,P. and Maran, J. 2009.Illegal domestic trade of the Philippine Forest Turtle (Siebenrockiella leytensis) in the Philippines. TurtleLog Number 3, http://www.iucn-tftsg.org/tln003/, doi:10.3854/ thn.003.2009.

GaulKe, M. and Altenbach,A.V. 2006. Die Sumpfschildkrötenfauna der Philippinen. Marginata 2006:48-53.

GaUlKe, M. AND Fritz, U. 1998. Distribution pattern of batagurid turtles in the Philippines. Herpetozoa 11(1/2):3-12.

Gavino, C.M. And Schoppe, S. 2004. First information on the trade of freshwater turtles in Palawan. Agham Mindanaw, Ateneo de Davao Journal of Science and Technology 2:53-60.

GonZalez, J.C., AfuAng, L.E., AND DE VeYra, R.R. 1997. Amphibians and reptiles. In: Wildlife Conservation Society of the Philippines (WCSP). Philippine Red Data Book. Bookmark, Inc., Makati City, Philippines.

Heaney, L.R. 1986. Biogeography of small mammals in Southeast Asia: estimates of rates of colonization, extinction and speciation.
Biological Journal of the Linnean Society 28:127-165.

ICZN [INTERnational COMMISSION ON ZOOLOGICAL NomenClature]. 1999. International Code of Zoological Nomenclature. Fourth Edition. The Natural History Museum, London, UK, 306 pp.

IUCN [INTERNATIONAL UNION FOR CONSERVATION OF NatURe]. 2012. 2012 IUCN Red List of Threatened Species. 2010.www. iucnredlist.org.

IvERSON, J.B. 1992. A Revised Checklist with Distribution Maps of the Turtles of the World. Privately printed, Richmond, Indiana, 363 pp.

KFI [KATALA FoundATION InC.]. 2007. Wildlife confiscation records from DENR and PCSD for the years 2000-2006. Katala Foundation Inc., Puerto Princesa City, Palawan, Philippines.

LEPITEN-TABAO,M.V. AND TABARANZA,JR.,B.R. 2004.Recent information on the trade of Indonesian parrots in the Philippines. Sylvatrop 13(1-2):107-118.

LOPEZ, M.F.M. AND SCHOPPE, S. 2004. Morphometry of four species of non-marineturtles from Palawan, Philippines with special reference to sexual dimorphism. Agham Mindanaw 2:41-51.

Mallari, N.A.D., TABARANZA, JR., B.R., AND Crosby, M.J. 2001. Key Conservation Sites in the Philippines: A Haribon Foundation and BirdLife InternationalDirectory of Important BirdAreas.Bookmark, Inc. Makati City, Philippines.

Matillano,J.2008.Status and dynamics of trade of Heosemys leytensis. CEPF Small Grant Final Project Completion Report, 12 pp.

McCord, W.P., Iverson, J.B., Spinks, P.Q., And Shaffer, H.B. 2000. A new genus of geoemydid turtle from Asia. Hamadryad 25(2):20-24.

MCDowell, S.B. 1964. Partition of the genus Clemmys and related problems in the taxonomy of aquatic Testudinidae. Proceedings of the Zoological Society of London 143:239-279.

McGuire, J.A. AND Alcala, A.C. 2000. A taxonomic revision of the flying lizards (Iguania: Agamidae: Draco) of the Philippine Islands, with a description of a new species. Herpetological Monographs 14:81-138.

PCSD[Palawan Council For SustainableDevelopment] .2006.PCSD Resolution 06-309-A-2006. The list of terrestrial and marine wildlife in Palawan and their categories pursuant to Republic Act 9147 or the "Wildlife Act." Palawan Council for Sustainable Development, Puerto Princesa City, Palawan, Philippines.

PhILIPPEN, H.D. 2006. Philippinische Erdschildkröte Siebenrockiella (Panyaenemys) leytensis (Taylor, 1920). Marginata 10:31-34.

SchopPE, S. 2006. Notes on the biology of the Philippine Forest Turtle Siebenrockiella leytensis (Taylor, 1920). Poster, 15th WCSP Annual Philippine Biodiversity Symposium, Puerto Princesa City, Palawan.

Schoppe, S. 2008a. Informationen zum Wachstum der Philippinischen Waldschildkröte (Siebenrockiella leytensis). Marginata 18, 5(2):52-57.

SCHOPPE, S. 2008b. Science in CITES: the biology and ecology of the Southeast Asian Box Turtle Cuora amboinensis and its uses and trade in Malaysia. TRAFFIC Southeast Asia, Petaling Jaya, Selangor, Malaysia.

SCHOPPE, S. 2009a. Status, trade dynamics and management of the SoutheastAsian Box Turtle Cuoraamboinensisin Indonesia.TRAFFIC Southeast Asia, Petaling Jaya, Selangor, Malaysia.

SCHOPPE, S. 2009b. Siebenrockiella leytensis over time - are populations stable? Final Report to Turtle Conservation Fund. Katala Foundation Inc., Puerto Princesa City, Palawan, Philippines.

SchopPE,S.2010.Husbandry guideline for the PhilippineForest Turtle. Turtle Survival Alliance Magazine 2010, pp. 86-89.

Schoppe, S. AND Acosta, D. 2010a. Siebenrockiella leytensis over time-are populations stable? Technical and financial interimreport to Turtle Conservation Fund. Katala Foundation Inc., Philippine 
Freshwater Turtle Conservation Program, Puerto Princesa City, Palawan, Philippines, 20 pp.

Schoppe, S. And Acosta, D. 2010b. BACOCO-Conservation of the Philippine Forest Turtle Siebenrockiella leytensis in Palawan. Performance and financial interim report to USFWS.Katala Foundation Inc., Philippine Freshwater Turtle Conservation Program, Puerto Princesa City, Palawan, Philippines, 52 pp.

Schoppe, S. AND AcostA, D. 2011. Siebenrockiella leytensis over time - are populations stable? Technical and financial interim report to Turtle Conservation Fund. Katala Foundation Inc., Philippine Freshwater Turtle Conservation Program, Puerto Princesa City, Palawan, Philippines, 21 pp.

Schoppe, S. AND AcostA, D. 2012. Siebenrockiella leytensis over time-are populations stable? Technical and financial interim report to Turtle Conservation Fund. Katala Foundation Inc., Philippine Freshwater Turtle Conservation Program, Puerto Princesa City, Palawan, Philippines, 22 pp.

Schoppe, S. And Cervancia, M. 2009. Herpetological surveys along Pagdanan Range and Dumaran Island, northern Palawan, Philippines. Hamadryad 34(1):95-106.

Schoppe, S. and Diaz, S. 2011. Philippine Forest Turtle assurance colony: improved husbandry and facilities provide optimism for the future of this challenging species. Turtle Survival Alliance Magazine 2011, pp. 89-91.

SCHOPPE, S. And FERnANdo, N. 2009. A range country colony for the Philippine Forest Turtle. Turtle Survival Alliance Magazine 2009, pp. 96-97.

SCHOPPE, S. AND IBAÑEZ,D. 2011.In-situ conservation of the Philippine Forest Turtle Siebenrockiella leytensis through informal education. Final report to North of England Zoological Society. Katala Foundation Inc., Philippine Freshwater Turtle Conservation Program, Puerto Princesa City, Palawan, Philippines, 73 pp.

Schoppe, S. Matillano, J., Cervancia, M., and Acosta, D. 2010. Conservation needs of the critically endangered Philippine Forest Turtle Siebenrockiella leytensis (Taylor, 1920) in Palawan. Chelonian Conservation and Biology 9(2):145-153.

SPINKS, P.Q., ShafFer, H.B., Iverson, J.B., AND McCord, W.P. 2004. Phylogenetic hypothesis for the turtle family Geoemydidae. Molecular Phylogenetics and Evolution 32:162-182.

TAYLOR, E.H. 1920. Philippine turtles. Philippine Journal of Science 16(2):111-144.

TAYLOR,E.H. 1922a.Additions to the herpetological fauna of thePhilippine Islands, I. Philippine Journal of Science 21:161-206.

TAYLOR,E.H.1922b.Additions to the herpetological fauna of the Philippine Islands, II. Philippine Journal of Science 21:257-303.

TAYLOR,E.H.1923.Additions to the herpetological fauna of the Philippine Islands, III. Philippine Journal of Science 22:515-557.

TAYLOR,E.H. 1925. Additions to the herpetological fauna of the Philippine Islands, IV. Philippine Journal of Science 26:97-111.

Turtle Conservation Coalition [Rhodin, A.G.J., Walde, A.D., Horne, B.D., van DiJK, P.P., Blanck, T., and Hudson, R. (Eds.)].
2011. Turtles in Trouble: The World's 25+ Most Endangered Tortoises and FreshwaterTurtles - 2011.Lunenburg, MA: IUCN/SSC Tortoise and Freshwater Turtle Specialist Group, Turtle Conservation Fund, Turtle Survival Alliance, Turtle Conservancy, Chelonian Research Foundation, Conservation International, Wildlife Conservation Society, and San Diego Zoo Global, 54 pp.

Turtle Taxonomy Working Group [van Dijk, P.P., Iverson, J.B., SHAFFER, H.B., Bour, R., AND RHODIN, A.G.J.]. 2011. Turtles of the world, 2011 update: annotated checklist of taxonomy, synonymy, distribution, and conservation status. In: Rhodin, A.G.J., Pritchard, P.C.H., van Dijk, P.P., Saumure, R.A., Buhlmann, K.A., Iverson, J.B., and Mittermeier, R.A. (Eds.). Conservation Biology of Freshwater Turtles and Tortoises: A Compilation Project of the IUCN/ SSC Tortoise and Freshwater Turtle Specialist Group. Chelonian Research Monographs No. 5, pp. 000.165-000.242, doi:10.3854/ crm.5.000.checklist.v4.2011, http://www.iucn-tftsg.org/cbftt/.

van DiJk, P.P., Stuart, B.L., and Rhodin, A.G.J. 2000. Asian Turtle Trade: Proceedings of a Workshop on Conservation and Trade of Freshwater Turtles and Tortoises in Asia. Chelonian Research Monographs No. 2, 164 pp.

VETTER,H. AND VAN DiJK,P.P.2006.TERRALOG: Turtles of the World Vol.4,East and SouthAsia.EditionChimaira/Aqualog Verlag ACS GmbH, Frankfurt am Main/Rodgau, Germany, 160 pp.

Welton, L.J., Siler, C.D., Linkem, C.W., Diesmos, A.C., Diesmos, M.L., Sy, E., AND BRown, R.M. In press. Dragons in our midst: phyloforensics of illegally traded Southeast Asian water monitor lizards. Biological Conservation.

Wermuth, H. And Mertens, R. 1961. Schildkröten, Krokodile,Brückenechsen. Gustav Fischer Verlag, Jena, Germany.

WIDMANN,P.1998.AGuide to the Ecosystems of Palawan,Philippines. ViSCA-GTZ and Times Edition, Singapore, $120 \mathrm{pp}$.

Widmann,P.,LAChENMAIER, K., Widmann,I.L., Schoppe, S., DumalaG, R.M.,Matillano,J.D.,VIlllafuerte,SD.F.,Diaz,H.,ANDCERVAnCia, M. 2004. Wirbeltiergemeinschaften in Rotsteißkakadu-Habitaten in Nord-Palawan. ZGAP Mitteilungen 20(2):3-7.

YUYEK, M. 2004. A perilous life: the natural history and ecological status of the Philippine Forest Turtle, Heosemys leytensis, from Palawan, with emphasis on care and feeding requirements in captivity. Animal Scene 4(7):80-82.

\section{Citation Format for this Account:}

Diesmos, A.C., BuskiRK, J.R., Schoppe, S., Diesmos, M.L.L., Sy, E.Y., AND BRown, R.M. 2012. Siebenrockiella leytensis (Taylor 1920) Palawan Forest Turtle, Philippine Forest Turtle. In: Rhodin,A.G.J., Pritchard, P.C.H., van Dijk, P.P., Saumure, R.A., Buhlmann, K.A., Iverson, J.B., and Mittermeier, R.A. (Eds.). Conservation Biology of Freshwater Turtles and Tortoises: A Compilation Project of the IUCN/SSC Tortoise and Freshwater Turtle Specialist Group. Chelonian Research Monographs No.5,pp.066.1-066.9, doi:10.3854/ crm.5.066.leytensis.v1.2012, http://www.iucn-tftsg.org/cbftt/. 